\title{
Use of cell cultures as an indicator of pathogenicity of free-living amoebae
}

\author{
RAY T. M. CURSONS AND TIM J. BROWN \\ From the Department of Microbiology and Genetics, Massey University, Palmerston North, New Zealand
}

SUMMARY Results comparing the time needed for the development of cytopathic effects in cell cultures with that needed to cause death in mice using inocula of Naegleria and Acanthamoeba are presented. The significance of the source and concentration of the inocula is demonstrated. The use of cell cultures as an indicator of the pathogenicity of free-living amoebae is discussed.

There is now sufficient epidemiological evidence to include the pathogenic free-living amoebae (PFI,A), which are the aetiological agents of primary amoebic meningoencephalitis (PAM), in the general group of waterborne diseases. It is becoming common practice to test for the presence of these organisms as well as for the traditional waterborne pathogens (Culbertson, 1971; Carter, 1972; Chang, 1974; Craun, 1976). The case reported by Anderson and Jamieson (1972) of a young child contracting PAM from a chlorinated domestic source, the 16 cases of the disease from an indoor municipal swimming pool (Červa, 1971a), and the numerous isolations of amoebae from public swimming areas (Chang, 1971, 1974; Červa, 1971a; Červa and Huldt, 1974; Brown and Cursons, 1977) indicate the extent of this problem.

From a public health viewpoint reliable tests for the rapid identification of both the pathogenic and nonpathogenic species of the amoebae are necessary for the control of the disease. An indirect fluorescent antibody (IFAB) method was reported to meet this need (van Dijck et al., 1974; de Jonckheere et al., 1975). However, the finding of mouse-nonpathogenic seropositive Naegleria fowleri (the causative agent of PAM) (de Jonckheere et al., 1975) indicates a need for further definitive and supporting tests, as outlined by Cursons and Brown (1976), to distinguish positively between pathogenic and nonpathogenic amoebic isolates. Traditionally, this has involved the use of experimental animals, particularly mice, which we have found exhibit a considerable variation in response to infection with PAM amoebae. Such variation has also been reported by Červa (1971b), Culbertson (1971),

Received for publication 20 June 1977
Anderson and Jamieson (1972), Phillips (1974), Diffley et al. (1976), and Adams et al. (1976). The alternative to an in vitro system is the use of chick embryos or cell cultures inoculated with amoebae for testing the virulence of environmental isolates and which can be used as a prelude to animal pathogenicity tests with considerable benefit. The purpose of this paper is to compare the reports of the use of cell cultures as indicators of pathogenicity of free-living amoebae and to report on recent experiments comparing the use of VERO (secondary monkey kidney cells) with mice and/or guinea-pigs.

\section{Material and methods}

\section{AMOEBAE}

$N$. fowleri strain HB-1, Naegleria gruberi strain

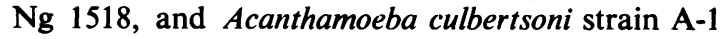
were supplied by the Culture Centre for Algae and Protozoa, Cambridge, UK. N. fowleri strains NTH, PA14, NHI, and MsT and $N$. gruberi strains Ng-27 and PL200f were obtained from Dr R. A. Robinson of the National Health Institute, Wellington, New Zealand. N. gruberi strains $\mathrm{BH}$ and $\mathrm{BL}$ were obtained from Ms N. Davies, of the Pathology Department of Hamilton Hospital, New Zealand. Acanthamoeba castellanii strain 1501, Acanthamoeba polyphaga strain P.23, and Naegleria jadini strain 0400 were obtained from Dr E. Willaert, Prins Leopold Institute of Tropical Medicine, Belgium. A. castellanii strains $B$ and $B_{1}$ were isolated from a frozen lake in Oslo, Norway (Brown and Cursons, 1977) and $A$. polyphaga strain NiA from a thermal pool in New Zealand.

All amoebae were grown monoxenically on either amoeba saline agar (Page, 1967) or NM agar 
(Fulton, 1970) overlaid with a lawn of Escherichia coli.

Strains Ng-27, PL200f, 0400, HB-1, NTH, PA14, NHI, and MsT were grown axenically in CYM medium and strains $\mathrm{Ng} \mathrm{1518,} \mathrm{BH,} \mathrm{and} \mathrm{BL}$ were grown axenically in TYG medium (O'Dell and Sevens, 1973). All Acanthamoeba spp. were cultured in $4.0 \%$ Neff medium (Stevens and O'Dell, 1973).

All strains were subcloned by the plaque method (Fulton, 1970). Cell numbers were estimated to give a total count using a modified bright-line Fuchs Rosenthal haemocytometer.

\section{CELL CULTURE}

All cell cultures were maintained in $250-\mathrm{ml}$ flatbottomed flasks, 10-ml Kimax tubes, or Falcon cell culture petri dishes. The growth medium (GM) consisted of Wellcome Eagles BHK supplemented with $10 \%$ tryptose phosphate broth and $10 \%$ bovine serum. The monolayer was washed with Eagles BHK and maintained with $\mathrm{GM}+2 \%$ fetal calf serum. All titrations and plaquing in cell culture were carried out by standard virological techniques.

\section{MOUSE PATHOGENICITY TESTS}

Young Swiss-White mice (10-16 g) were anaesthetised by the intraperitoneal injection of $0.15 \mathrm{ml}$ of a $1 \%$ $\mathrm{v} / \mathrm{v}$ nembutal solution. All mice were then inoculated intranasally with $0.1 \mathrm{ml}$ of a $10^{6}$ cells $/ \mathrm{ml}$ axenic suspension.

SCANNING ELECTRON MICROSCOPY (SEM) VERO cells were cultured on glass coverslips (diameter $18 \mathrm{~mm}$ ) placed in plastic petri dishes. After the desired incubation period the cells were fixed in $6 \%$ glutaraldehyde in $0.1 \mathrm{M} \mathrm{Na}$-cacodylate$\mathrm{HCl}$ buffer with $0.1 \mathrm{M}$ sucrose $\mathrm{pH} 7.2$ (previously heated to $37^{\circ} \mathrm{C}$ ) for three hours at $4^{\circ} \mathrm{C}$. The cells were then washed twice with cold $0.15 \mathrm{M} \mathrm{Na}$ cacodylate- $\mathrm{HCl}$ buffer (pH 7.2) and postfixed in $2 \% \mathrm{O}_{\mathrm{s}} \mathrm{O}_{4}$ in S-collidine buffer ( $\left.\mathrm{pH} 7 \cdot 4\right)$ for 60 minutes. They were then thoroughly washed with distilled water, plunged into liquid air, and freeze-dried in an Edwards Freeze Drier EFO3 (using liquid air as the desiccant) at $10^{-2}$ torr for four hours. The cells were then fixed onto the stub with silver conductive paint, vacuum coated with gold in a Film Vac. Inc. Mini-Coater, and viewed using a CV/IKSCAN 100 SEM operated at $16 \mathrm{kV}$.

\section{Results}

Table 1 shows that all mouse-pathogenic strains form cytopathic effects (CPE) in VERO cell culture whereas they are not formed by the non-pathogenic strains. Tables 2 and 3 show the effect of inoculum concentration and the difference in virulence between amoebae passaged in cell culture and those grown in axenic culture.

Typical CPE, such as rounding up of cells (Fig. 3), will develop as early as 8-12 hours, depending on the concentration of the inoculum and the age of the culture. If a lower inoculum concentration and/or older culture is used then the CPE are also slower to appear. This is followed by a steady degeneration of the monolayer with refractility due to granulation and vacuolation of the VERO cells leading to eventual total disruption of the monolayer within 24-48 hours (Figs. 4 and 5).

Animal pathogenicity studies, on the other hand, have been rather less consistent. Table 1 shows that when using either pathogenic Naegleria or Acanthamoeba strains there is a considerable variation in the number of animals that succumb, the incubation period (that is, time between infection and onset of symptoms), and the period of time before death. This variation is due mainly to the individual susceptibility of the animal and the difficulty of being repeatedly precise when using intranasal inoculation.

\section{Discussion}

The formation of CPE by PFLA on cell monolayers depends on a number of varying factors such as the virulence of the amoebae, the concentration and age of the inoculum (Stevens and O'Dell, 1974), and the susceptibility of the cell monolayer type. The strains of $N$. fowleri which cause complete disruption of the cell monolayer in two days take two to five times as long to kill mice (Table 1). Similar results are seen with $A$. culbertsoni (Table 1). Using $A$. castellanii and $A$. polyphaga, the time for complete disruption of the cell monolayer is usually one to two days earlier than the time needed to cause the first mouse deaths. The difference in time needed for CPE development is a direct result of the more rapid growth rate of $N$. fowleri in cell culture as compared with Acanthamoeba species (Chang, 1971), and of the greater virulence of $N$. fowleri than pathogenic Acanthamoeba (Tables 2 and 3). It is rare for all mice to die after inoculation with $A$. castellanii or A. polyphaga (Table 1).

Table 2 shows clearly that for similar sized inocula of $N$. fowleri those amoebae grown in cell culture produce CPE one day earlier than those grown in axenic culture and that for either culture method the reduction of the inoculum concentration by a power of 10 will lengthen the time needed for the development of CPE by one day. This indicates that passag 


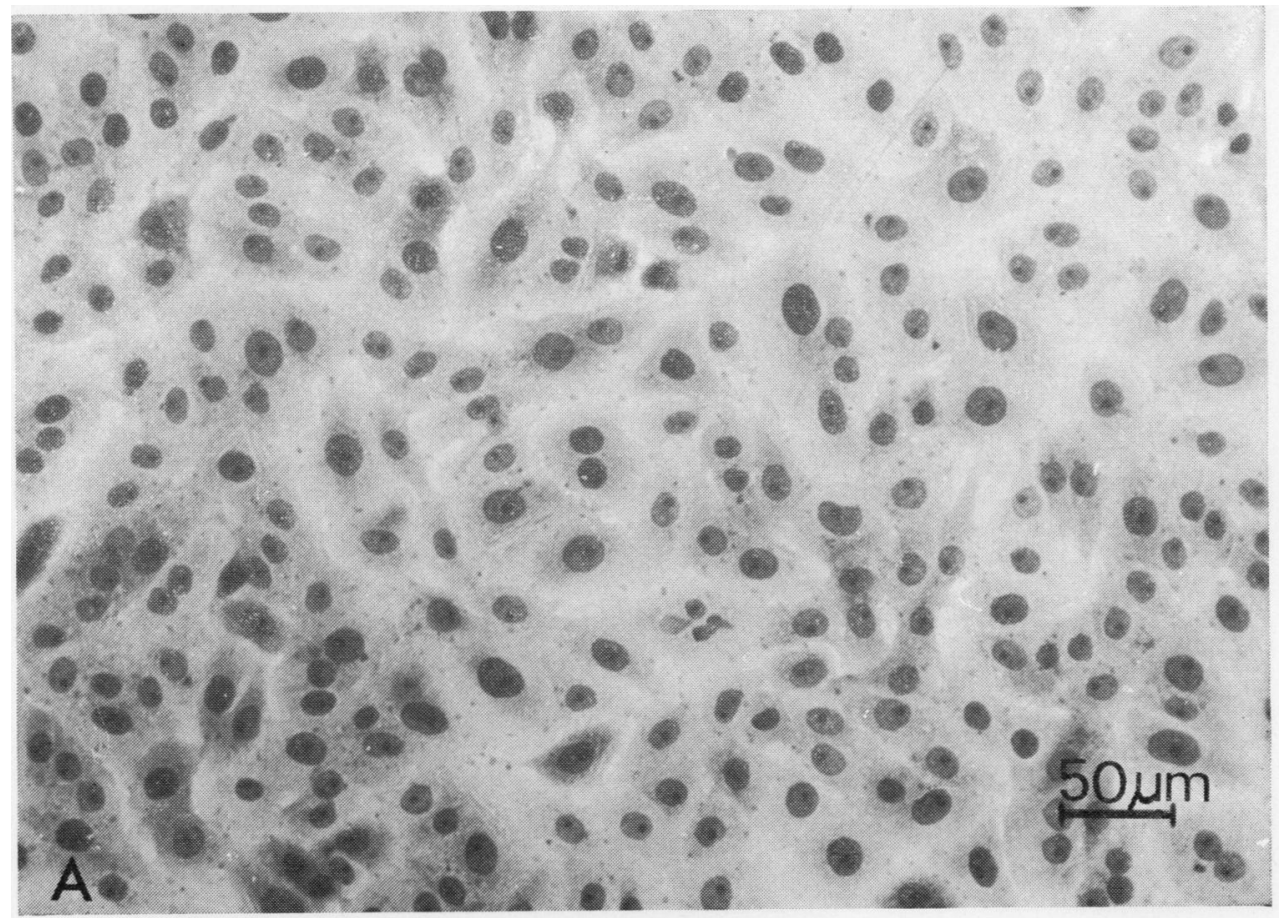

Fig. 1 Control VERO cell monolayer: (A) light micrograph $(L M) ;(B)$ scanning electron micrograph (SEM). 

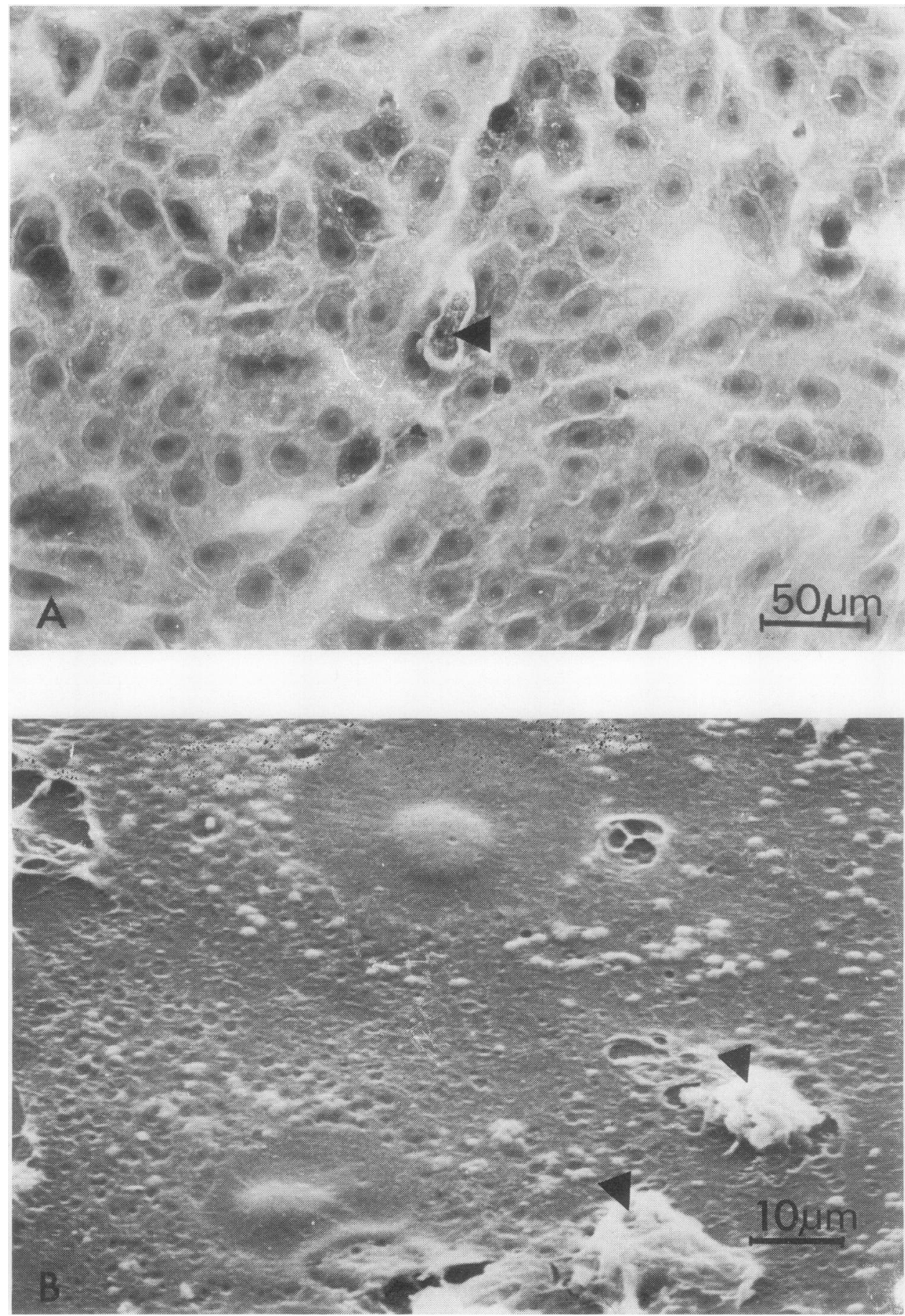

Fig. 2 VERO cell culture showing beginning of cytopathic effects (CPE) (stage I) and amoeba cells (N. fowleri strain MsT) indicated by arrows; (A) LM; (B) SEM. 

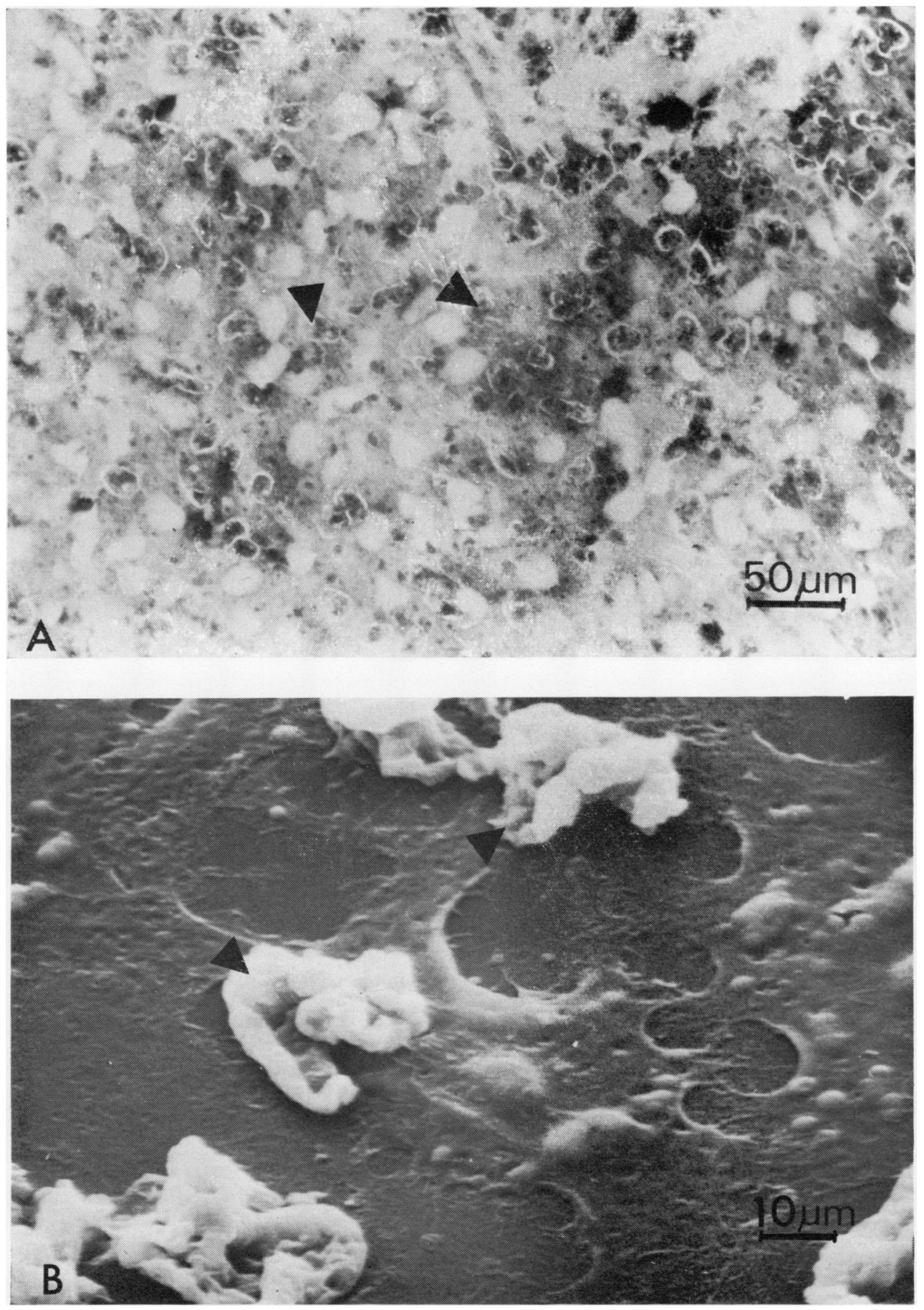

Fig. 3 VERO cell culture showing pronounced CPE (stage II) with widespread areas of breakdown and numerous amoebae ( $\mathrm{N}$. fowleri strain $M S T$ ), some of which are indicated by arrows;

(A) $L M$; (B) SEM. 

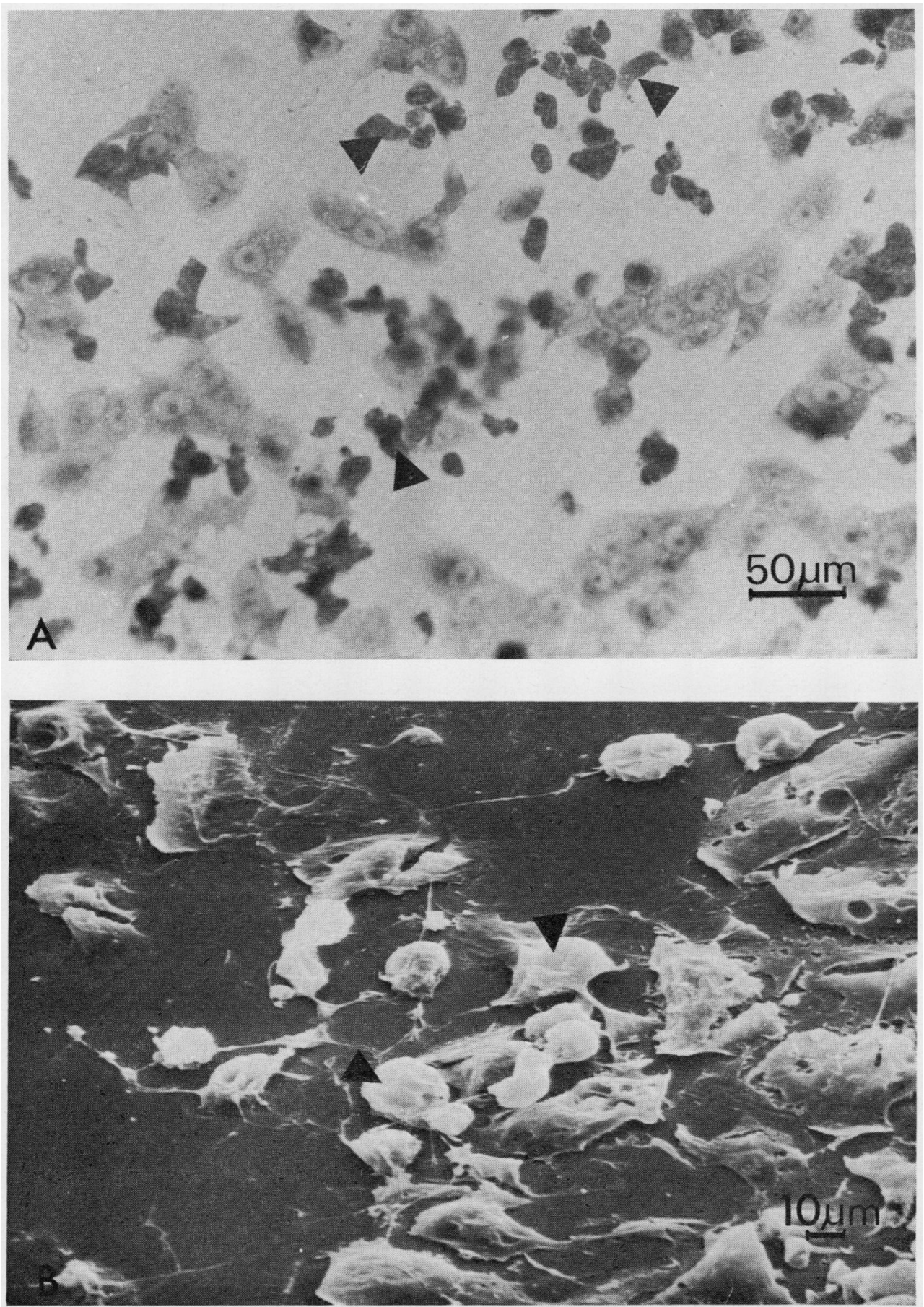

Fig. 4 Pronounced CPE (stage III) showing only isolated islands of VERO cells and many amoebae (N. fowleri strain MsT), some of which are indicated by arrows; $(A) L M ;(B) S E M$. 

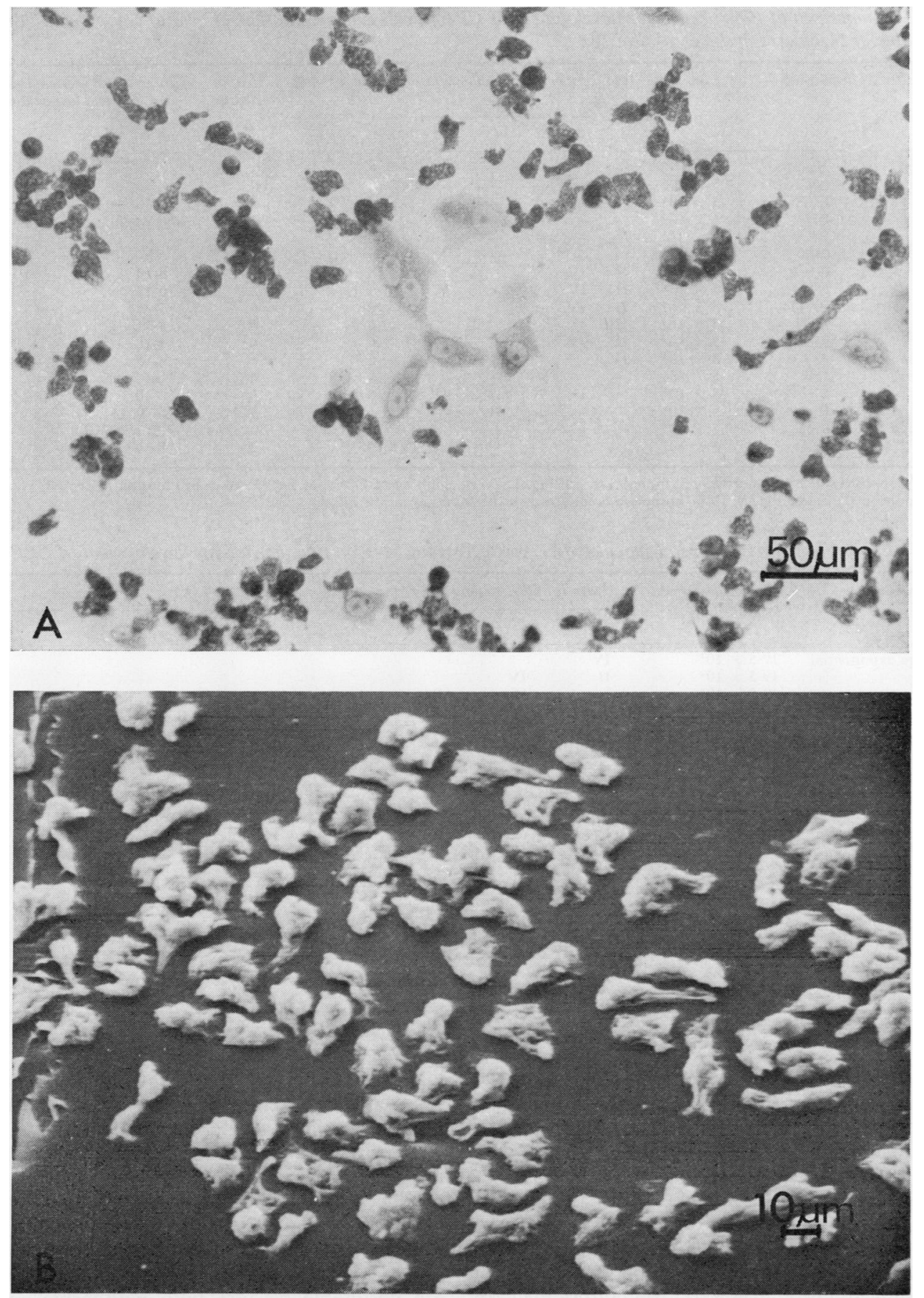

Fig. 5 Complete breakdown of VERO cell monolayer showing only a few cells: remaining amoebae (N. fowleri strain MsT) dominate the culture (stage IV); (A) LM; (B) SEM. 
Table 1 Comparison of time needed for development of CPE in cell culture and that needed to cause death in mice using strains of Naegleria and Acanthamoeba

\begin{tabular}{|c|c|c|c|c|c|c|c|c|c|c|c|}
\hline \multirow[t]{2}{*}{ Species } & \multirow[t]{2}{*}{ Strain } & \multirow[t]{2}{*}{$\begin{array}{l}\text { Conc. of } \\
\text { inoculum }\end{array}$} & \multicolumn{6}{|c|}{$\begin{array}{l}\text { No. of days for development of } \\
\text { CPE }\end{array}$} & \multirow[t]{2}{*}{$\begin{array}{l}\text { No. of mice } \\
\text { used }\end{array}$} & \multirow[t]{2}{*}{$\begin{array}{l}\text { No. of } \\
\text { deaths }\end{array}$} & \multirow[t]{2}{*}{$\begin{array}{l}\text { Interval between inoculation } \\
\text { and first and last deaths (days) }\end{array}$} \\
\hline & & & 1 & 2 & 3 & 4 & 5 & 6 & & & \\
\hline \multirow[t]{5}{*}{ N. gruberi } & $\mathrm{Ng}-2 \mathrm{l}$ & $5 \times 10^{4}$ & - & - & - & - & - & - & 0 & $u$ & \\
\hline & $\mathrm{Ng}-1518$ & $5 \times 10^{4}$ & - & - & - & - & - & - & 6 & 0 & \\
\hline & PL200f & $5 \times 10^{4}$ & - & 一 & - & - & - & - & 6 & 0 & \\
\hline & BH & $5 \times 10^{4}$ & - & - & - & - & - & - & 6 & $\mathbf{0}$ & Not applicable \\
\hline & BL & $5 \times 10^{4}$ & - & - & - & - & - & - & 6 & 0 & \\
\hline N. jadini & 0400 & $5 \times 10^{4}$ & - & - & - & - & - & - & 6 & 0 & \\
\hline \multirow[t]{5}{*}{$N$ fowleri } & HB-1 & $5 \times 10^{4}$ & II & IV & & & & & 6 & 5 & $8-13$ \\
\hline & NTH & $5 \times 10^{4}$ & II & IV & & & & & 6 & 2 & $10-12$ \\
\hline & PA14 & $5 \times 10^{4}$ & II & IV & & & & & 6 & 6 & 7- 8 \\
\hline & NHI & $5 \times 10^{4}$ & III & IV & & & & & 6 & 6 & $6-11$ \\
\hline & MsT & $5 \times 10^{4}$ & III & IV & & & & & 6 & 6 & $5-18$ \\
\hline A. culbertsoni & A-1 & $5 \times 10^{4}$ & IV & & & & & & 6 & 6 & 4- 5 \\
\hline \multirow[t]{3}{*}{ A. castellanii } & 1501 & $5 \times 10^{4}$ & - & - & - & - & - & - & 6 & 0 & Not applicable \\
\hline & B & $5 \times 10^{4}$ & - & I & 1 & II & IV & & 6 & 4 & 6-10 \\
\hline & $\mathbf{B}_{1}$ & $5 \times 10^{4}$ & - & - & I & II & IV & & 6 & 4 & 6- 9 \\
\hline \multirow[t]{2}{*}{ A. polyphaga } & P. 23 & $5 \times 10^{4}$ & - & - & - & - & - & 一 & 6 & 0 & Not applicable \\
\hline & $\mathrm{NiA}$ & $5 \times 10^{4}$ & - & - & 一 & I & II & IV & 6 & 2 & $8-10$ \\
\hline
\end{tabular}

$(\mathrm{CPE}=$ cytopathic effects; - normal cell monolayer, see Fig. $1 ; \mathrm{I}=$ beginning of CPE, see Fig. 2 ; II = pronounced CPE, see Fig. 3 ; III = very pronounced CPE, see Fig. 4 ; IV = complete breakdown of the monolayer, see Fig. 5)

Table 2 Effect of source and size of inocula of $\mathrm{N}$. fowleri strain MsT on time needed for development of CPE

\begin{tabular}{|c|c|c|c|c|c|c|c|c|c|}
\hline \multirow[t]{2}{*}{ Source of inoculum } & \multirow{2}{*}{$\begin{array}{l}\text { Size of inoculum } \\
(\text { cells } / \mathrm{ml})\end{array}$} & \multicolumn{8}{|c|}{ Days for CPE to develop } \\
\hline & & 1 & 2 & 3 & 4 & 5 & 6 & 7 & 8 \\
\hline \multirow{3}{*}{$\begin{array}{l}\text { Cefl culture exponential } \\
24 \mathrm{~h}\end{array}$} & $19.5 \times 10^{4}$ & IV & & & & & & & \\
\hline & $\begin{array}{l}19 \cdot 5 \times 10^{2} \\
19 \cdot 5 \times 10^{1}\end{array}$ & I & $\begin{array}{l}\text { II } \\
\text { II }\end{array}$ & III & IV & & & & \\
\hline & $19.5 \times 10^{2}$ & - & - & - & - & I & III & IV & \\
\hline \multirow[t]{5}{*}{ Axenic exponential $24 \mathrm{~h}$} & $18.5 \times 10^{4}$ & II & IV & & & & & & \\
\hline & $18.5 \times 10^{3}$ & - & I & II & IV & & & & \\
\hline & $18.5 \times 10^{2}$ & - & - & I & II & IV & & & \\
\hline & $18.5 \times 10^{1}$ & - & - & I & I & II & IV & & \\
\hline & $18 \cdot 5$ & - & - & - & I & I & III & IV & \\
\hline \multirow{5}{*}{$\begin{array}{l}\text { Cell culture exponential } \\
24 \mathrm{~h}\end{array}$} & $3.4 \times 10^{4}$ & IV & & & & & & & \\
\hline & $3.4 \times 10^{3}$ & II & IV & & & & & & \\
\hline & $3.4 \times 10^{2}$ & I & II & III & IV & & & & \\
\hline & $3.4 \times 10^{1}$ & - & - & - & II & IV & & & \\
\hline & $3 \cdot 4$ & - & - & - & - & I & II & IV & \\
\hline \multirow{5}{*}{ Axe.ic exponential $24 \mathrm{~h}$} & $3.4 \times 10^{4}$ & II & IV & & & & & & \\
\hline & $3.4 \times 10^{3}$ & - & I & II & IV & & & & \\
\hline & $3.4 \times 10^{2}$ & - & - & - & II & IV & & & \\
\hline & $3.4 \times 10^{1}$ & - & - & - & - & I & II & IV & \\
\hline & $3 \cdot 4$ & - & - & - & - & - & - & - & - \\
\hline
\end{tabular}

For explanation of symbols, see Table 1

ing the amoebae through cell culture increases the virulence of the amoebae.

Table 3 shows a similar relationship between inoculum size and source of culture, that is, cell culture or axenic culture, using $A$. culbertsoni although the time pattern of CPE formation is less regular. Using low concentrations of inocula of axenic $A$. culbertsoni there is an apparent loss of virulence even though Acanthamoeba species will grow axenically in Eagles BHK cell culture medium whereas Naegleria species will not. This is due to the high salt concentration of the Eagles medium which is amoebicidal to Naegleria srecies. The apparent loss of virulence of Acanthamoeba when passaged in axenic culture as opposed to mice has been reported by Stevens and O'Dell (1974).

The choice of the cell line does not seem as important as it is in virus infections, amoebae being able to produce CPE in such common cell lines as VERO Hep-2, MDBK, HEL, and HEK. Others have used Pig Kidney, HeLa, PMI, SIRC, and mouse melanoma. Chang (1971), however, states that HeLa cells are unsuitable because both pathogenic and nonpathogenic amoebae produce CPE in this cell line.

The CPE formed by the amoebae on the monolayer appear to be due both to the liberation of a "cyto- 
Table 3 Effect of source and size of inocula of A. culbertsoni strain A-1 on time needed for development of CPE

\begin{tabular}{|c|c|c|c|c|c|c|c|c|c|}
\hline \multirow[t]{2}{*}{ History of inoculum } & \multirow{2}{*}{$\begin{array}{l}\text { Size of inoculum } \\
(\mathrm{cells} / \mathrm{ml})\end{array}$} & \multicolumn{8}{|c|}{ Days for CPE to develop } \\
\hline & & 1 & 2 & 3 & 4 & 5 & 6 & 7 & 8 \\
\hline $\begin{array}{l}\text { Cell culture exponential } \\
24 \mathrm{~h}\end{array}$ & $\begin{array}{l}30 \times 10^{4} \\
30 \times 10^{3} \\
30 \times 10^{2} \\
30 \times 10^{1} \\
30\end{array}$ & $\begin{array}{l}\text { IV } \\
\text { IV } \\
\text { I } \\
-\end{array}$ & $\begin{array}{l}\text { III } \\
\text { I }\end{array}$ & $\begin{array}{l}\text { IV } \\
\text { II } \\
\end{array}$ & $\begin{array}{l}\text { IV } \\
\text { I }\end{array}$ & II & III & IV & \\
\hline \multirow[t]{3}{*}{ Axenic exponential $24 \mathrm{~h}$} & $\begin{array}{l}30 \times 10^{4} \\
30 \times 10^{3} \\
30 \times 10^{2}\end{array}$ & $\begin{array}{l}\text { IV } \\
\text { II } \\
\end{array}$ & IV & - & II & III & IV & & \\
\hline & $30 \times 10^{1}$ & - & - & - & - & - & - & - & - \\
\hline & 30 & - & - & - & - & - & - & - & - \\
\hline \multirow[t]{4}{*}{$\begin{array}{l}\text { Cell culture exponential } \\
24 \mathrm{~h}\end{array}$} & $\begin{array}{l}3 \times 10^{4} \\
3 \times 10^{3}\end{array}$ & $\underline{\text { II }}$ & IV & II & IV & & & & \\
\hline & $3 \times 10^{2}$ & - & - & - & - & - & II & III & IV \\
\hline & $3 \times 10^{1}$ & - & - & - & - & - & - & - & - \\
\hline & 3 & - & - & - & - & - & - & $\div$ & - \\
\hline \multirow[t]{4}{*}{ Axenic exponential $24 \mathrm{~h}$} & $\begin{array}{l}3 \times 10^{4} \\
3 \times 10^{3}\end{array}$ & $\div$ & II & IV & I & II & III & IV & \\
\hline & $3 \times 10^{2}$ & $\therefore$ & - & - & - & - & - & - & - \\
\hline & $3 \times 10^{1}$ & - & - & - & - & -- & - & - & - \\
\hline & 3 & - & - & - & - & - & - & - & - \\
\hline
\end{tabular}

For explanation of symbols, see Table 1

toxic substance' and to actual phagocytosis of the cells by the amoebae, as is seen by using a cell-free filtrate from exponentially growing amoebae passaged in cell culture, and the observation of cell culture debris in the food vacuoles of trophozoites (Chang, 1971, 1974; Visvesvara and Callaway, 1974). In $A$. culbertsoni this 'cytotoxic substance' has been identified as a phospholipase (Visvesvara and Balamuth, 1975), and, more recently, Chang (1976) has also identified a "phospholipolytic enzyme or factor' in Naegleria. On the other hand, Schuster and Dunnebacke (1974) have described two different intracellular agents in the genus Naegleria, one of which is a virus-like particle (VLP) present only in $N$. gruberi and is not associated with the formation of CPE in cell cultures; the second is an infectious agent present in both $N$. gruberi and $N$. fowleri forming CPE specifically in secondary chick fibroblast cells but not in other cell cultures. Further, this 'Naegleria ameba infectious material' (NAIM) was obtained using a lysate from a monoxenic culture as opposed to the cell-free filtrate used by us.

The use of cell cultures also avoids the many reported instances of variations in individual susceptibility of laboratory animals (Table 1) (Anderson and Jamieson, 1972; Phillips, 1974; Diffley et al., 1976; Adams et al., 1976). Initially, mice were anaesthetised with ether for the intranasal route but this was changed to nembutal as it was found that residual ether in the nasal cavity lysed amoebae. Although this improved the percentage fatality it is still difficult to quantitate the actual number of trophozoites by this route due to sneezing and swallowing by the mice. Other routes, such as subcutaneous (Culbertson, 1971; Diffley et al., 1976), intravenous, and intraperitoneal (Adams et al., 1976), have also been tried with limited success because of the individual response of the animal.

In our experience, cytopathogenicity of known human and environmental isolates in cell culture has mirrored the pathogenicity in laboratory animals. Chang (1971, 1974), Carter (1972), and Culbertson (1971) have also found this correlation to be experimentally reproducible. Thus cell cultures provide a rapid diagnostic test to indicate the pathogenicity of PFLA and should be used in conjunction with other tests such as the indirect fluorescent antibody test and animal pathogenicity testing. Cell cultures have the advantage over the latter of $(a)$ rapidity; $(b)$ selecting the more virulent organisms of the population for subsequent use in animal pathogenicity tests; (c) providing an axenic source of inoculation, and $(d)$ allowing a quantitative estimate to be made of the amoebic population by plaquing in cell culture (Fulton, 1970) (Fig. 6).

We wish to acknowledge the financial support of the New Zealand Health Department for this work, and thank Mr D. Hopcroft of the Electron Microscope Unit, DSIR. Palmerston North for his help. The 


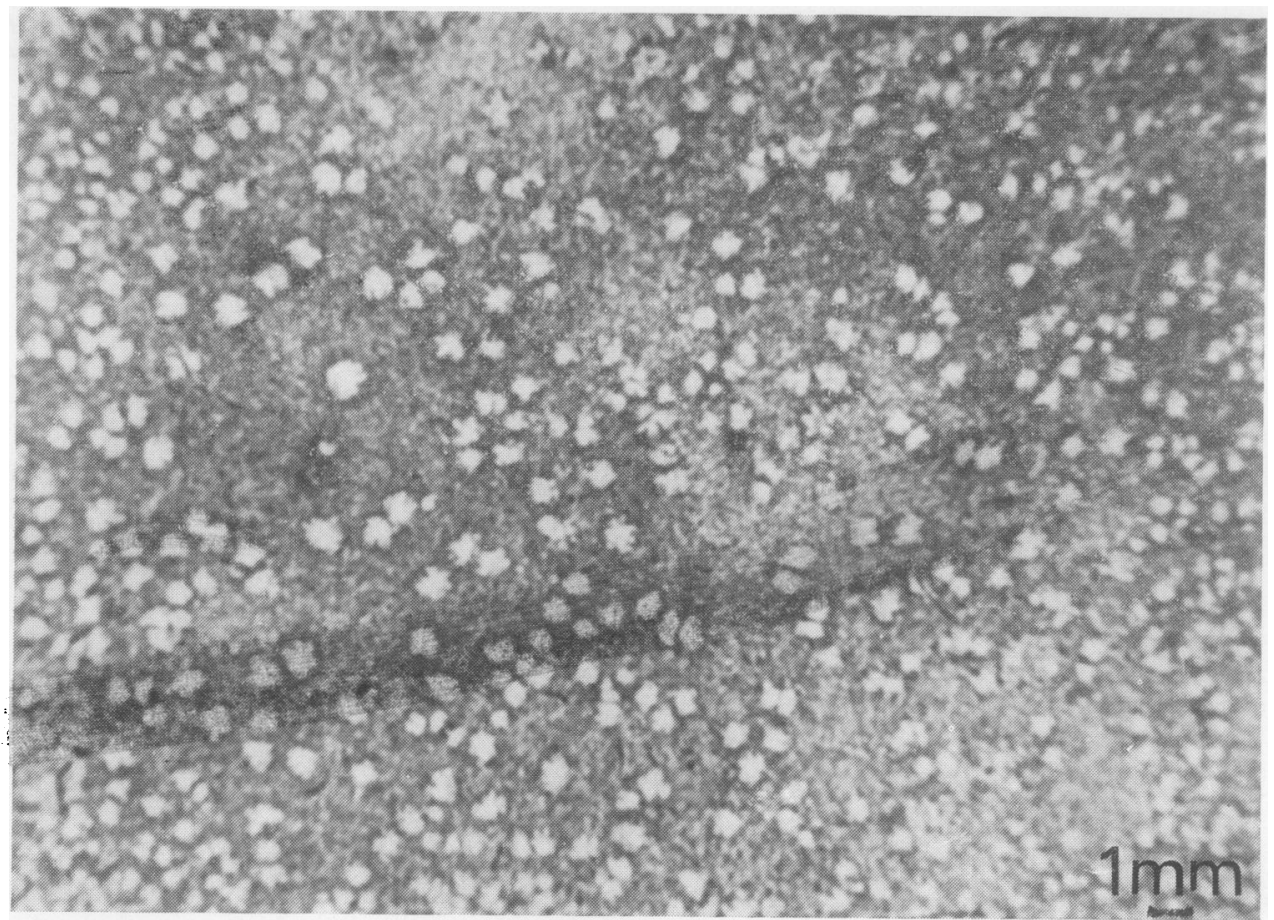

Fig. 6 Light micrograph of VERO cell monolayer showing plaques cleared by amoebae (N. fowleri strain MsT). Each plaque represents one amoeba cell in the inoculum.

technical assistance of Miss M. Stewart, Department of Microbiology and Genetics, Massey University, was much appreciated.

\section{References}

Adams, A. C., John, D. T., and Bradley, S. G. (1976). Modification of resistance of mice to Naegleria fowleri infections. Infection and Immunity, 13, 13871391.

Anderson, K., and Jamieson, A. (1972). Primary amoebic meningoencephalitis (Letter). Lancet, 1, 902-903.

Brown, T. J., and Cursons, R. T. M. (1977). Pathogenic amoebae from frozen swimming areas in Oslo, Norway. Scandinavian Journal of Infectious Diseases (in press).

Carter, R. F. (1972). Primary amoebic meningo-encephalitis. An appraisal of present knowledge. Transactions of the Royal Society of Tropical Medicine and Hygiene, 66, 193-213.

Cerva, L. (1971a). Studies of Limax amoebae in a swimming pool. Hydrobiologia, 38, 141-161.

Červa, L. (1971b). Experimental infection of laboratory animals by the pathogenic Naegleria gruberi strain Vitek. Folia Parasitologica 18, 171-176.

Cerva, L., and Huldt, G. (1974). Limax amoebae in five swimming pools in Stockholm. Folia Parasitologica, 21, 71-75.
Chang, S. L. (1971). Small free-living amebas: cultivation, quantitation, identification, classification, pathogenesis and resistance. In Current Topics in Comparative Pathobiology, 1, edited by T. C. Cheng, pp. 201-254. Academic Press, New York.

Chang, S. L. (1974). Etiological, pathological, epidemiological and diagnostical considerations of primary amebic meningo-encephalitis. CRC Critical Reviews in Microbiology, 135-159.

Chang, S. L. (1976). Pathogenesis of pathogenic Naegleria amoeba. From Joint Meeting of the American Society of Tropical Medicine and Hygiene and the Royal Society of Tropical Medicine and Hygiene, 3-5 November, 1976.

Craun, G. F. (1976). Microbiology-waterborne outbreaks. Journal of the Water Pollution Control Federation, 48, 1378-1397.

Culberston, C. G. (1971). The pathogenicity of soil amebas. Annual Review of Microbiology, 25, 231-254.

Cursons, R. T. M., and Brown, T. J. (1976). Identification and classification of the aetiological agents of primary amebic meningo-encephalitis. New Zealand Journal of Marine and Freshwater Research, 10, 245-262.

van Dijck, P., de Jonckheere, J., Reybrouck, G., and van de Voorde, H. (1974). Rapid identification of Naegleria species by sero-agglutination and fluorescent antibodies-new possibilities for the water supply ser- 
vices. Zentralblatt für Bakteriologie, Parasitenkunde, Infektionskrankheiten und Hygiene, I. Abt. Orig. B, 158, 541-551.

Diffley, P., Skeels, M. R., and Sogandares-Bernal, F. (1976). Delayed type hypersensitivity in guinea pigs infected subcutaneously with Naegleria fowleri Carter. Zietschrift für Parasitenkunde, 49, 133-137.

Fulton, C. (1970). Amebo-flagellates as research partners. In Methods in Cell Physiology, Vol. IV, edited by D. M. Prescott, pp. 341-476. Academic Press, New York.

de Jonckheere, J., van Dijck, P. G., and van de Voorde, H. (1975). The effect of thermal pollution on the distribution of Naegleria fowleri. Journal of Hygiene, 75, 7-13.

O'Dell, W. D., and Stevens, A. R. (1973). Quantitative growth of Naegleria in axenic culture. Applied Microbiology, 25, 621-627.

Page, F. C. (1967). Taxonomic criteria for Limax amoebae, with descriptions of 3 new species of Hartmannella and 3 of Vahlkampfia. Journal of Protozoology, 14, 499-521.
Phillips, B. P. (1974). Naegleria: another pathogenic ameba. Studies in germfree guinea pigs. American Journal of Tropical Medicine and Hygiene, 23, 850-855.

Schuster, F. L., and Dunnebacke, T. H. (1974). Viruslike particles and an unassociated infectious agent in amoebae of the genus Naegleria. Annales de la Société Belge de Médicine Tropicale, 54, 359-370.

Stevens, A. R., and O'Dell, W. D. (1973). The influence of growth medium on axenic cultivation of virulent and avirulent Acanthamoeba. Proceedings of the Society of Experimental Biology and Medicine, 143, 474-478.

Stevens, A. R., and O'Dell, W. D. (1974). In vitro growth and virulence of Acanthamoeba. Journal of Parasitology, 60, 884-885.

Visvesvara, G. S., and Balamuth, W. (1975). Comparative studies on related free-living and pathogenic amebae with special reference to Acanthamoeba. Journal of Protozoology, 22, 245-256.

Visvesvara, G. S., and Callaway, G. S. (1974). Light and electron microscopic observations on the pathogenesis of Naegleria fowleri in mouse brain and tissue culture. Journal of Protozoology, 21, 239-250. 